\title{
AN EXTRAORDINARY RAVEN NEST
}

PETER TAYLOR, Box 597, Pinawa, MB, R0E 1L0, E-mail: <taylorp@granite.mb.ca>

While entering Whiteshell Provincial Park along Manitoba Provincial Road 307 east of Seven Sisters Falls on 29 April 2008, I noticed an unusual structure in a mature Aspen Poplar (Populus tremuloides) about $50 \mathrm{~m}$ south of the road, just inside the park boundary. A quick look through binoculars revealed a Common Raven's head showing above a 2metre-deep column of sticks (Figure 1). The raven soon flushed, leaving no doubt about its identity. The extraordinary structure seemed to consist of at least four distinct nestlike masses piled on top of one another. A similar but smaller structure nearby was about 1 metre deep (Figure 2).

I had noticed ravens nesting at this spot in previous years, but had not seen anything unusual about the nests. The small grove of poplars is adjacent to Big Creek, a marshy backwater of the Winnipeg River, and is surrounded by mostly coniferous forest, much of which was clear-cut in winter 2007-2008. Part of this cutting was a timber salvage operation following a severe windstorm on the night of 23-24 June 2007.

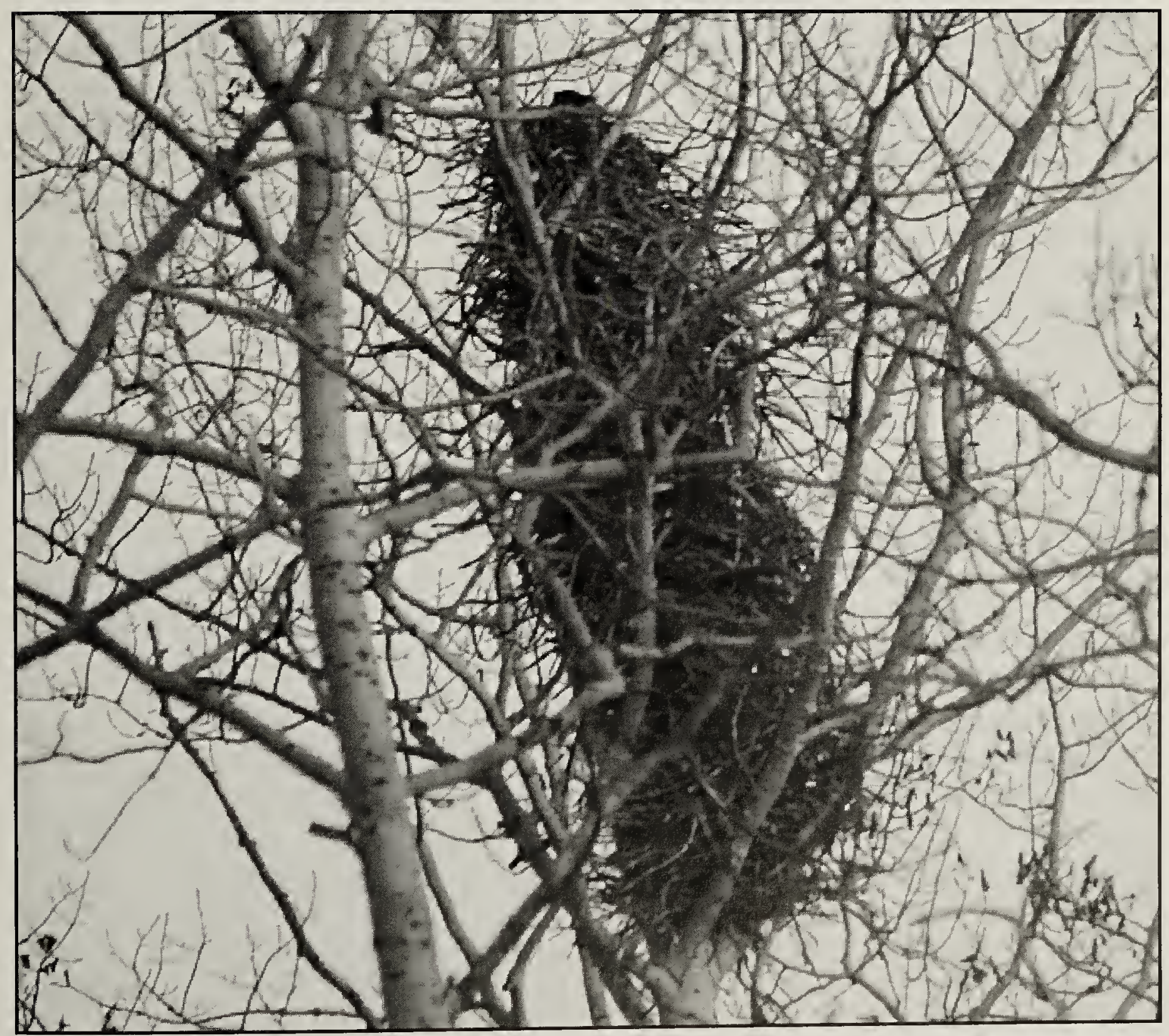

Figure 1. Common Raven nest east of Seven Sisters Falls, MB, 29 April 2008; a sitting adult's head is just visible.

P. Taylor 


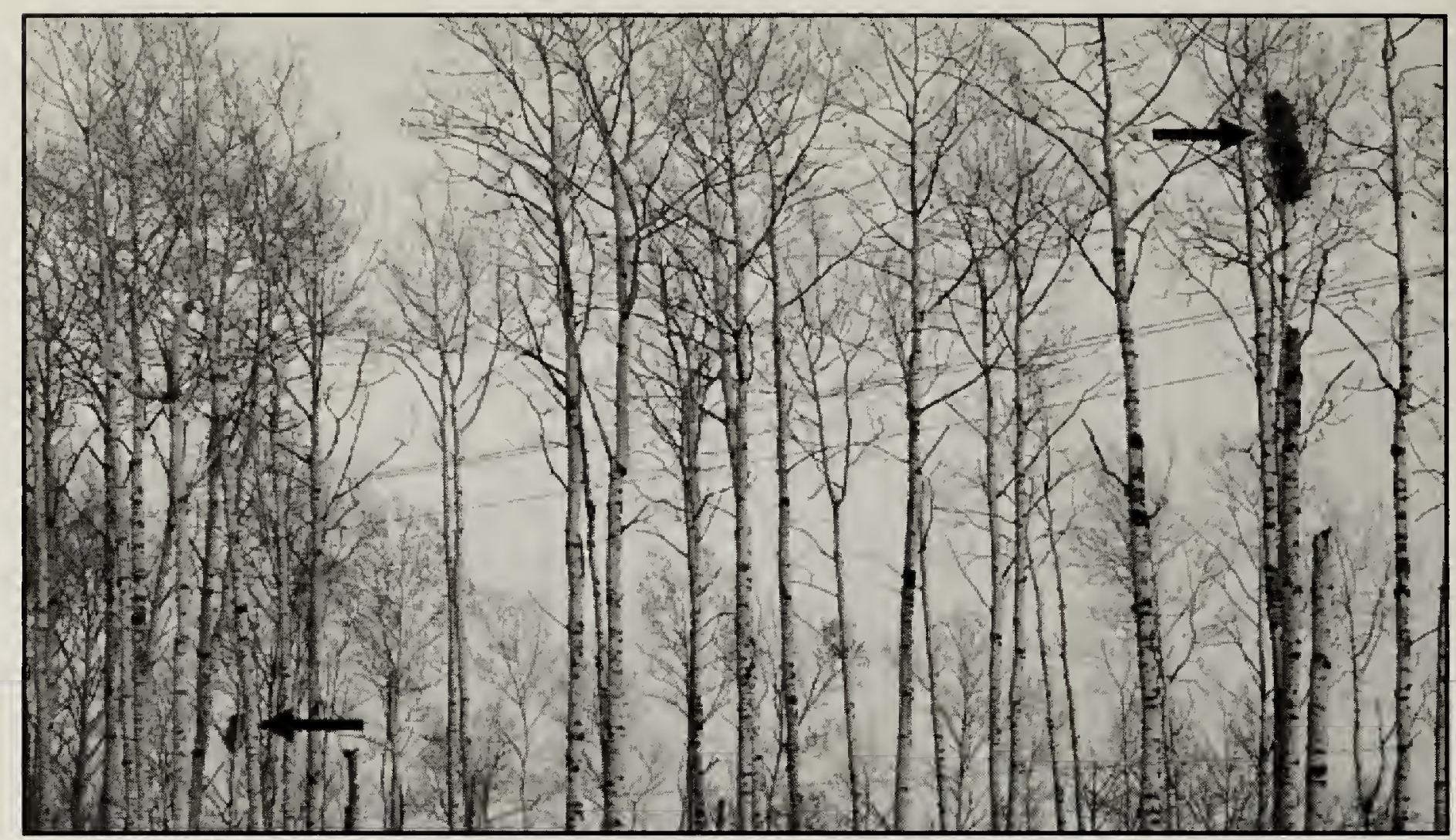

Figure 2 Wide-angle view of the Aspen Poplar stand, with arrows indicating both unusual nests.

P. Taylor

The nest was observed four more times between 3 and 16 May. On 3 May, it was unoccupied, but a raven was soaring nearby. On 4 May, one bird was sitting on the nest with its presumed mate perched nearby. On 6 May, Rudolf Koes visited the nest; it was unoccupied but a raven was carrying nesting material in the vicinity! On 16 May, Sharon Taylor and I saw one bird sitting on the nest at the end of a windy day with gusts over $40 \mathrm{~km} /$ h. I did not visit again until 26 May, by which time the nest had collapsed, leaving only a shallow remnant. Strong winds on 17 and 21 May, and/or winds and a heavy rainstorm on 25 May, had evidently proved too much for this ambitious structure. I found a mass of sticks under the tree, but no sign of nest lining or contents, which may well have been destroyed. The nest had leaned about $15^{\circ}$ off vertical, following the upper trunk, with limited lateral support from branches, so its destruction was disappointing but not surprising.

The structure of the nest suggested it was the product of several years of rebuilding and refurbishing, but there is good reason to believe that most of it was built in spring 2008. I pass the area several times per year on birding outings, often between late fall and early spring, and had not noticed the nest before. Nor had Rudolf Koes, who covers the area annually as part of the Pinawa-Lac du Bonnet Christmas Bird Count. Furthermore, it is highly unlikely that such a structure would have survived the violent windstorm of 2324 June 2007, which felled or damaged trees in about 244 square kilometres of Whiteshell Provincial Forest and Provincial Park. ${ }^{1}$ The nest site is at the western extremity of the storm-affected area.

One can only speculate as to what prompted the ravens to build such a structure, and what were the possible roles of disease, injury, abnormal breeding condition, disturbance, or other factors. The birds seem to have become locked into the process of nest construction, and had not progressed to nest-lining and egg-laying in the normal sequence. Usually ravens in the Whiteshell region can be seen in 
aerial courtship flights in February, and nest construction or refurbishment gets underway around mid-March (my earliest such record is 4 March). Noisy, well-feathered young are typically visible in nests by the second half of May, with fledging as early as 25 May. Other raven nests in the area in 2008 appeared to follow this normal schedule, despite the cool, slow spring. The unusual nest appeared to be well behind schedule at best-not surprising, given the extra construction effort!

I have found no references to similar raven nests. According to Boarman and Heinrich, ${ }^{2}$ the female Common Raven apparently does most of the construction, with the male assisting by bringing sticks to the nest or performing some of the construction. Tree nests typically consist of a base of large sticks and other available materials (such as bones and wire), wedged into a crotch and woven into a rough basket. An inner cup is woven from smaller branches and twigs. The bottom of the cup is sometimes lined with mud, wool, fur, shredded bark, grasses, or other soft materials. ${ }^{2}$ Raven nests are often asymmetrical, and range in shape from $40-153 \mathrm{~cm}$

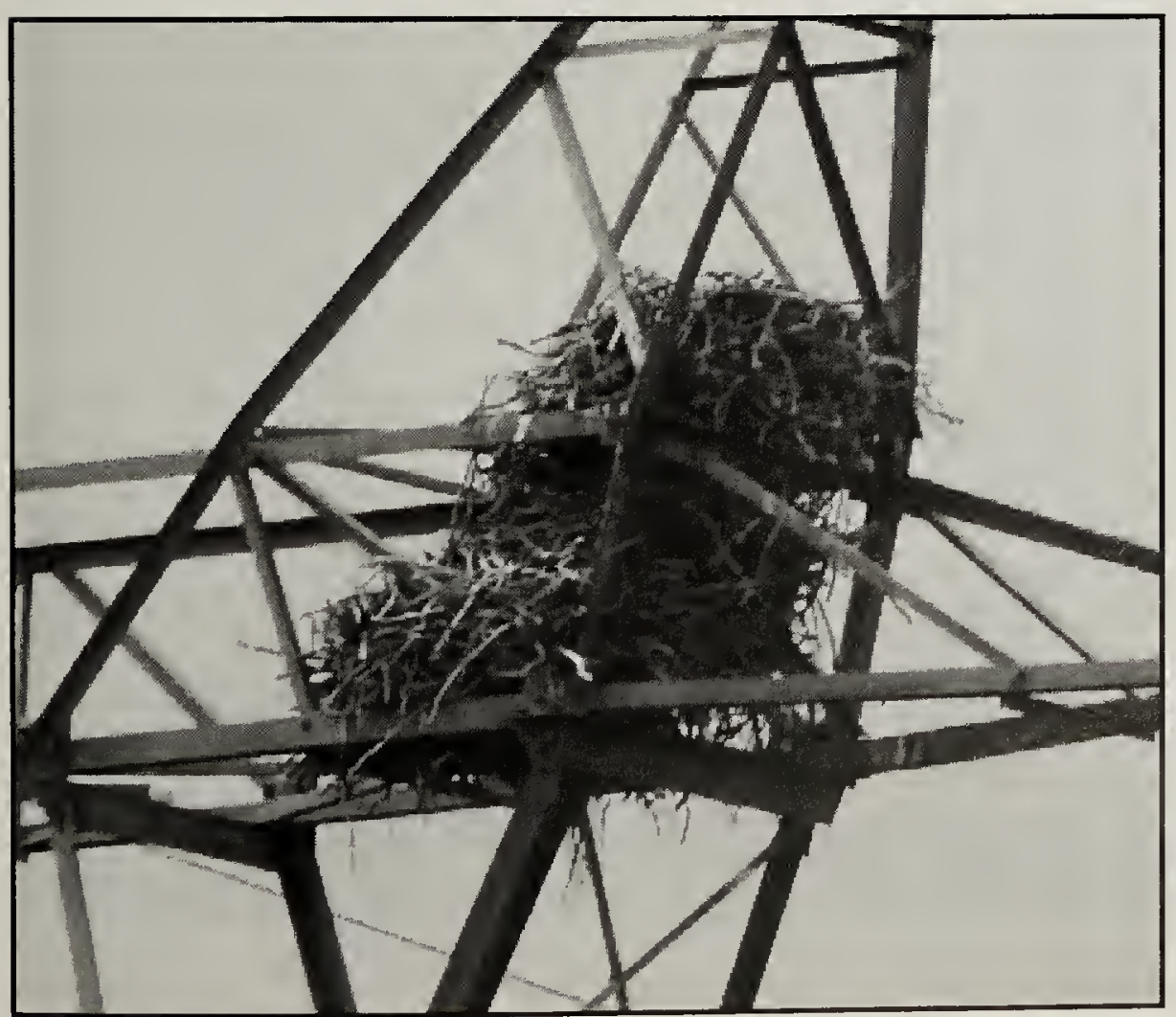

Figure 3 Empty Common Raven nest along Hwy 60 southwest of Easterville, MB, 23 June 2008. P. Taylor diameter, 20-61 $\mathrm{cm}$ high, with the interior cup 22-30 cm diameter and $13-15 \mathrm{~cm}$ deep. ${ }^{2}$ Nests are frequently reused or rebuilt.

Ravens often build their nests on electricity transmission towers and similar steel structures, even in forested areas. They are a particularly common sight on transmission towers in the Grand Rapids region of westcentral Manitoba. On 23 June 2008, I noticed several such nests (empty by then) along Highway 60 in the Easterville area southwest of Grand Rapids. Among these were some unwieldy double- and triple-decker structures bearing some resemblance to the Whiteshell nest, but not nearly so high (Figure 3 ). The particular design of the towers on this transmission line seemed to offer good lateral support for these nests.

1 ANONYMOUS. 2007. Whiteshell timber salvage plan. Manitoba Conservation, available online at www.gov.mb.ca/conservation/forestry.

2. BOARMAN, W.L. and B. HEINRICH. 1999. Common Raven (Corvus corax). In The Birds of North America, No. 476 (A. Poole and F. Gill, eds.). The Academy of Natural Sciences, Philadelphia, PA.; The American ornithologists Union, Washington, DC. 